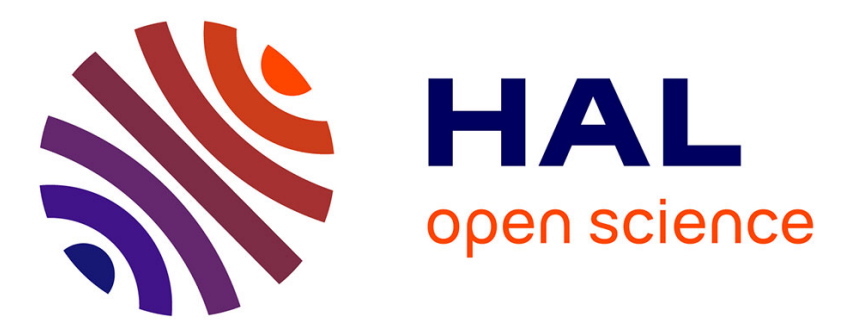

\title{
The Moderating Effects of Explanatory Style in Physical Education Performance: A Prospective Study
}

\author{
Charles Martin-Krumm, Philippe Sarrazin, Christopher Peterson
}

\section{To cite this version:}

Charles Martin-Krumm, Philippe Sarrazin, Christopher Peterson. The Moderating Effects of Explanatory Style in Physical Education Performance: A Prospective Study. Personality and Individual Differences / Journal of Personality and Individual Differences, 2005, 38, pp.1645-1656. 10.1016/j.paid.2004.09.023 . hal-00388998

\section{HAL Id: hal-00388998 \\ https://hal.science/hal-00388998}

Submitted on 27 May 2009

HAL is a multi-disciplinary open access archive for the deposit and dissemination of scientific research documents, whether they are published or not. The documents may come from teaching and research institutions in France or abroad, or from public or private research centers.
L'archive ouverte pluridisciplinaire HAL, est destinée au dépôt et à la diffusion de documents scientifiques de niveau recherche, publiés ou non, émanant des établissements d'enseignement et de recherche français ou étrangers, des laboratoires publics ou privés. 
Running head: The Moderating Effects of Explanatory Style

The Moderating Effects of Explanatory Style in Physical Education Performance:

A Prospective Study

Charles P. Martin-Krumm ${ }^{\text {a }}$, Philippe G. Sarrazin ${ }^{\text {b, }}$, Christopher Peterson ${ }^{\mathrm{c}}$

Personality and Individual Differences, 38, 1645-1656.

${ }^{a}$ Centre de Recherche sur l'Enseignement, l'Apprentissage, et la Didactique (CREAD),

IUFM-Rennes II, and IFEPS Angers, France.

${ }^{\mathrm{b}}$ Laboratoire Sport et Environnement Social, UFRAPS, Université J. Fourier Grenoble 1, BP 53 - 38041 Grenoble Cedex 9 France.

${ }^{\mathrm{c}}$ University of Michigan, USA

Total word count: 4995

* Corresponding author:

Tel: +33476514229

Fax: +33475781554

E-mail address: philippe.sarrazin@ujf-grenoble.fr (P.G. Sarrazin) 
The Moderating Effects of Explanatory Style in Physical Education Performance:

\title{
A Prospective Study
}

\begin{abstract}
Explanatory style (ES) reflects the way people usually explain disparate bad or good events involving the self. The purpose of this study was twofold: (a) to test whether ES moderates the effect of perceived ability on students' expectancies and subjective task value, and (b) to explore the mediating effects of success expectancies and subjective task value in the relationships between ES and students' grades in physical education classes (GPEC). A oneyear prospective study was conducted with 182 high school students in physical education classes. First, regression analyses corroborated that ES interacted with perceived ability to predict success expectancies and subjective task value. An optimistic ES reduced the effects of a low perceived ability on subjective task value, whereas a pessimistic ES increased its harmful effects. Moreover, the more optimistic ES, the higher success expectancies are. Second, structural equation modelling analysis showed that ES had only a distal effect on students' GPEC and was mediated by more proximal variables such as success expectancies and subjective task value.
\end{abstract}

KEY WORDS: explanatory style, optimistic, pessimistic, value, success expectancies, achievement, motivation, physical education. 
The Moderating Effects of Explanatory Style in Physical Education Performance:

\section{A Prospective Study}

Explanatory style reflects the way that people habitually explain disparate bad or good events (e.g., Peterson, 2000; Peterson \& Steen, 2002). People who usually explain bad events with causes that are stable over time ("it's going to last forever"), global in effect ("it's going to undercut everything that I do"), and internal ("it's me") and who explain good events with unstable, specific, and external causes are said to have a pessimistic explanatory style ${ }^{1}$. People with the opposite attributional pattern are said to have an optimistic explanatory style. Explanatory style has been extensively investigated as a correlate of many outcomes such as depression (e.g., Volpe \& Levin, 1998), physical health (e.g., Dua, 1995), illness (e.g., Jackson, Sellers, \& Peterson, 2002), as well as athletic (e.g., Martin-Krumm, Sarrazin, Peterson, \& Famose, 2003) and occupational (e.g., Corr \& Gray, 1995) performance.

The study of explanatory style in the field of education has also received a considerable amount of attention (see Houston, 1994, for review). Following predictions of the reformulated model of learned helplessness (Abramson, Seligman, \& Teasdale, 1978), researchers have tested the hypothesis that a pessimistic explanatory style increases the probability of learned helplessness. For example Peterson and Barrett (1987) measured college students' explanatory style during the first two weeks of the academic year. They found that students with a pessimistic style performed worse than those with an optimistic style (in terms of grade point average at the end of the academic year). Nevertheless, since this study has been conducted, other investigations have yielded inconsistent results. Some of them support a positive link between a pessimistic explanatory style and academic failure (e.g., Henry, Martinko, \& Pierce, 1993 ; Petripin \& Johnson, 1991), others found no such link 
(e.g., Bridges, 2001 ; Fazio \& Palm, 1998 ; Tiggemann \& Crowley, 1993), and still others found the opposite association (e.g., Houston, 1994).

If it is possible to invoke some differences between participants or procedures to account for these divergent results, other explanations exist. In accordance with helplessness theory, it is possible that explanatory style functions only as a "distal" variable - a mere risk factor among others (e.g., Peterson \& Park, 1998). However, most studies treat explanatory style as a direct predictor of academic success. It is not surprising that controlling for variables which directly influence academic performance - as, for example, aptitude (e.g., Bridges, 2001) - mitigates the effect of explanatory style. It may also be that explanatory style interacts with other variables responsible for the motivational processes at school, increasing or decreasing their effects on academic success. Accordingly the present study attempted to integrate explanatory style and an academic motivation model.

Eccles and her colleagues' model is particularly useful in predicting behavior at school (e.g., Eccles, Adler, Futterman, Goff, Kaczala, Meece, \& Midgley, 1983; Eccles \& Wigfield, 2002). According to it, success expectancies and subjective task value are the two most immediate predictors of achievement behavior like task choices, persistence in an activity, strength involvement, and performance (see for a review Wigfield \& Eccles, 2000). Expectancies for success are defined as individuals' beliefs about how well they will do on upcoming tasks (see Eccles \& Wigfield, 2002). According to Eccles et al.'s model (1983), they are influenced by goals and more general self-schemata. In this study, we focused only on self-views in discrete and specific areas, namely the self-concept of one's ability in a subject because particular beliefs are generally better predictors of behavior than general beliefs (e.g., Pajares \& Schunk, 2001). Self-concept of one's ability, or perceived ability, can be defined as an individual perception of the actual competence in a particular subject (e.g., Eccles \& Wigfield, 2002). Thus, the concepts of success expectancies and perceived ability 
can be distinguished insofar as the latter corresponds to the ability at a given moment in a general domain (e.g., the "sport", or a particular kind of sport), whereas the formers are "projections" (thus focused on future) onto someone's capacity to succeed in a particular task or activity.

Eccles and her colleagues (1983) defined task value in terms of four major components: (a) intrinsic value (enjoyment of the activity), (b) utility value (usefulness of the task in terms of current and future goals), (c) attainment value (personal importance of doing well at the task), and (d) cost (perceived negative aspects of engaging in the task). Among the different antecedents of subjective task value, Eccles et al. again underlined the importance of goals and more general self schemata. For example, McIver, Stipek, and Daniels (1991) showed that changes in students' (aged 12 to 15 years) perceived ability over one semester predicted changes in their interest for subject matter, much more than the reverse.

In short, according to Eccles et al.'s model, the student who perceives high ability will develop high success expectancies and high subjective task value, which in turn will positively influence his/her grade point average. Conversely, the dynamics will be negative for a student who perceives low ability in this subject.

We were especially interested in the nature of this hypothesized negative spiral. Is a low perceived ability student expected to have only low success expectancies and subjective task value? We think this process may be more complex, and that perceived ability interacts with explanatory style to predict success expectancies and subjective task value, as shown by the dotted arrows on the Figure 1 which summarizes the theoretical model of this study. If a high perceived ability is associated with high success expectancies and task value, we further expected that explanatory style would moderate the harmful consequences of low perceived ability. A pessimistic explanatory style coupled with low perceived ability should lead to poorer success expectancies and task value than in the case for which low perceived ability is 
associated with an optimistic explanatory style. Indeed, we think that students who feel incompetent in physical education (PE) at the beginning of the school year, but who think this condition to be transitory and circumscribed (i.e., the optimistic students) will attend to progress during the academic year. These opportunities will result in more increased success expectancies and task value than those who consider this condition to be chronic and pervasive (i.e. the pessimistic students).

-Insert FIGURE 1 approximately here-

In summary, the present research was conducted in PE classes and had two primary aims. The first one was to test in a prospective design the moderating effects of the explanatory style on the relationships between students' perceived ability and their success expectancies and subjective task value in PE. More precisely, we expected that explanatory style would interact with perceived ability to predict success expectancies and subjective task value: (a) an optimistic style inhibits the effects of a low perceived ability on success expectations and subjective task value, (b) a pessimistic style exacerbates the effects of a low perceived ability on success expectations and subjective task value.

The second aim was to test the possibility that explanatory style has only distal effects on outcomes. We expected that its influence on students' achievement would be mediated by more proximal variables: success expectancies and subjective task value (see figure 1).

\section{Method}

\section{Participants and procedure}

Seventy-four boys and 108 girls aged 13 to $15(M=14$ years, $S D=0.86)$ agreed to participate in the study which was described to them as dealing with motivation at school. 
They were registered in 10 forms (8th and 9th grade) from a secondary school in France. Parental and school administrator permissions were requested before starting the investigation. At the beginning of the academic year, participants filled in a questionnaire assessing their explanatory style and their perceived ability in PE. One month later, students' success expectancies and subjective task value in PE were assessed. Lastly, at the end of the academic year, the grade point average of the participants was ascertained in PE classes.

\section{Questionnaire Measures}

\section{Explanatory Style}

Although explanatory style is conceptualized as a trait, some theorists (e.g., Cutrona, Russel, \& Jones, 1985) have recommended a domain-specific assessment of this construct. Therefore, a sport-specific measure was used. Participant completed an adapted French version of the Sport Attributional Style Scale (Hanrahan, Grove, \& Hattie, 1989), called the Sport and PE Explanatory Style Questionnaire (SPEESQ; Martin-Krumm, Sarrazin, Fontayne, \& Famose, 2001; Martin-Krumm et al., 2003). It consists of 10 hypothetical situations: 5 good outcomes (e.g., 'You perform very well in a course') and 5 bad outcomes (e.g., 'Your teacher claims that you are a very bad performer"). The positive and negative items were matched for content. Respondents are asked to imagine each event happening to them and to write the one major cause of this event, and then use 7-point bipolar scales in each case to rate the degree of stability and globality of the cause. In the former studies (Martin-Krumm et al., 2001), confirmatory factor analysis carried out on more than 600 teenagers provided strong support for the two correlate dimensions for both positive and negative events (GFI, NFI, CFI $>.93$; RMSR $<.045$ ). Factor loadings $(\lambda)$ exceed .50 , and the correlations between stable and 
global latent factors, disattenuated for error measurement, were equal to .42 and .34

respectively for the positive and the negative events. A satisfactory reliability of the tool was also found: internal consistency were .78 and .72 , and test-retest reliability over 6 months were .49 and .63 , respectively for the positive and negative events. Construct validity was supported by significant correlations and in the expected directions between the SPEESQ dimensions and ASQ dimensions $(r \mathrm{~s}>.60, p<.001)$, or success expectations and procrastination in $\mathrm{PE}$.

In the present sample, a composite score for explanations of bad events $(\mathrm{CN})$ was obtained by averaging the participant's score on the stability + globality dimensions for the bad events $(\alpha=.65)$. Similarly, a composite for good event explanations (CP) was calculated by averaging the respondent's score on the two dimensions for the good events $(\alpha=.73)$.

Finally, subtracting CN from CP yielded a full scale score (CPMCN). The more positive this score is, the more optimistic the participant is. By contrast, the more negative this score, the more the participant is pessimistic (see Peterson, 1991; Reivich, 1995, for a more detailed explanation)

\section{Perceived Ability in PE}

To assess perceived ability in PE, a 3-item questionnaire similar to the one developed by Nicholls and colleagues (e.g., Nicholls, Patashnick, \& Nolen, 1985) was used (e.g., 'When you practice sports and you compare yourself to most friends of your age, you feel...'). The answers are indicated on a 7-point scale anchored by 'very bad' (1) and 'very good' (7). In previous research conducted on teenagers (e.g., Sarrazin, Roberts, Cury, Biddle, \& Famose, 2002), the questionnaire has shown good construct validity, internal consistency $(\alpha>$.78), test-retest stability over 10 weeks $(r=.77)$, and predictive validity. In the present study, the 
internal consistency was high $(\alpha=81)$; consequently the average was computed and used in subsequent analyses.

\section{$\underline{\text { Success Expectation in PE }}$}

To assess students' success expectations in PE, a 3-item questionnaire similar to the one developed by Eccles and colleagues (e.g., Wigfield \& Eccles, 2000) was used (e.g., 'How do you think you will perform this year'). The answers are indicated on a 7-point scale anchored by 'very bad' (1) and 'very good' (7). In this study, the internal consistency was high $(\alpha=.91)$; consequently the average was computed and used in subsequent analyses.

\section{Subjective Task Value}

The value of PE was measured with a 3-item questionnaire like the one developed by Eccles and colleagues (e.g., Wigfield \& Eccles, 2000). The attainment value [e.g., 'To succeed in PE is for me...'(not important at all... very important)], utility value [e.g., 'I consider everything I learn in PE to be (not useful at all... very useful) to do things outside the school, or later'], and cost of engaging in PE [e.g., 'It costs me a lot to practice PE (not at all... tremendously); item to be reversed] are measured in a 7-point scale. In this study, the internal consistency was correct $(\alpha=.79)$; consequently the average was computed and used in subsequent analyses.

\section{$\underline{\text { Achievement in PE }}$}


According to several studies (e.g., Peterson \& Barrett, 1987), the average of the grades in Physical Education class (GPEC) at the end of the academic year has been used as an indicator of achievement during PE classes.

\section{Results}

\section{$\underline{\text { Analyses }}$}

Two sets of analyses were carried out to test the hypotheses. Hierarchical regression models were first used to test the moderating effects of the explanatory style on the links between perceived ability and success expectations or subjective task value ${ }^{2}$. Secondly, a path analysis was carried out with Lisrel 8.30 software (Jöreskog \& Sörbom, 1999) in order to test the model shown in Figure 1.

Means, standard deviations, and correlations between each variable of the study are presented in Table 1. All the variables were significantly intercorrelated ${ }^{3}$. Particularly, students' GPEC were strongly correlated with (a) perceived ability in PE and success expectancies ( $r=.62$ and $.63, p<.001$, respectively), (b) moderately with subjective task value $(r=.45, p<.01)$, and (c) weakly to explanatory style $(r=.26, p<.05)$.

\section{Predicting success expectations and subjective task value}

The hierarchical regression model was constructed as follows: The explanatory style and perceived ability were entered at Step 1, and explanatory style by perceived ability interaction was entered at Step 2. Following Aïken and West (1991), all the measured predictor variables were standardised. 


\section{Prediction of the success expectations}

The overall model was significant, $F(3,178)=99.67, p<.0001 ; R^{2}=.63$. Simple effect analyses showed (a) a positive effect of perceived ability $(b=.66, p<.001)$, (b) a nonsignificant effect of explanatory style $(b=.025, p=.66)$, and (c) a significant effect of the interaction. $(b=.06, p=.025)$. The interaction terms accounted for a small but statistically significant portion of the variance in predicting success expectations $\left(\Delta \mathrm{R}^{2}=.01, p=.025\right)$. Fig. 2a shows the slope of perceived ability at low (1 SD below the mean) and high (1 SD above the mean) levels of explanatory style. Perceived ability predicted success expectancies more strongly when explanatory style was optimistic $(b=.73 v s .59$, respectively for the more optimistic and the more pessimistic).

\section{Prediction of subjective task value}

The overall model was significant, $F(3,178)=28.48, p<.0001 ; R^{2}=.32$. Simple effect analyses showed significant effects of perceived ability $(b=.242, p<.01)$, explanatory style ( $b$ $=.42, p<.001)$, and interaction term. $(b=-.21, p<.001)$. This interaction term accounted for a significant portion of the variance in predicting subjective task value $\left(\Delta \mathrm{R}^{2}=.06, p<.001\right)$.

Fig. $2 \mathrm{~b}$ shows the slope of perceived ability at low ( $1 S D$ below the mean) and high (1 SD above the mean) levels of explanatory style. The analysis revealed that perceived ability significantly predicted the subjective task value for the pessimistic subjects $(b=.48, p<.001)$, but not for the optimistic ones $(b=.007, n s)$. 
Test of the theoretical model

Our path model was analyzed using the Lisrel 8.30 statistical package (Jöreskog \& Sörbom, 1999) with maximal likelihood criterion and covariance matrix. In order to limit the effect of multicolinearity, both independent variables and the interaction term were standardized (Kim, Kaye, \& Wright, 2001). The model provided a poor fit to the data, $\chi^{2}(3, N$ $=182)=11.08, p=.011, \mathrm{GFI}=.98, \mathrm{NFI}=.97, \mathrm{AGFI}=.86, \mathrm{RMR}=.059$. An important residual remained between perceived ability and students' GPEC (3.26). Adding a path between perceived ability and students' GPEC considerably improved the goodness-of-fit indices, $\chi^{2}(2, N=182)=0.27, p>.85, \mathrm{GFI}=1.00, \mathrm{NFI}=1.00, \mathrm{AGFI}=.99, \mathrm{RMR}=.02 . \mathrm{The}$ standardized path coefficients of this modified model are displayed in Figure 3.

-Insert FIGURE 3 approximately here-

First, the results revealed that the higher the student's success expectations $(\beta=.33)$, perceived ability $(\beta=.30)$, and subjective task value $(\beta=.13)$, the higher his/her grade point average. Second, similarly to the former hierarchical regression analyses, the two interaction terms were significant (simultaneously tested), confirming that ES moderated the links between perceived ability and subjective task value on one hand $(\beta=-.20)$, and between perceived ability and success expectations on the other hand $(\beta=.08)$. Lastly, a direct path was added between the explanatory style and students' GPEC in order to test if ES was related to students' achievement when expectancies and values were included in the model. It was not significant $(\beta=-.01, t=0.17)$ and did not increase the model's goodness-of-fit, corroborating that ES had only a distal effect on students' GPEC, and that this effect was mediated by success expectancies and subjective task value. 
Discussion

This study was designed to explore (a) whether ES moderates the effect of perceived ability on students' expectancies and subjective task value, and (b) the mediating effects of success expectancies and subjective task value in the relationships between ES and students' grade in physical education classes.

First, in accordance with former studies in the field of moderating effects played by the explanatory style (Jackson et al., 2002), the results showed that explanatory style interacted with perceived ability to predict subsequent success expectancies and subjective task value. More specifically, an optimistic explanatory style decreased the effects of a low perceived ability on subjective task value, whereas a pessimistic explanatory style increased its harmful effects (Figure 2b). In this case, lowering the value one attaches to difficult activities is likely to be an effective way to maintain a positive global sense of efficacy and self-esteem (see Eccles, Wigfield, \& Schiefele, 1998; Harter 1990; Seligman, 1991) - this strategy is useless for those who have an optimistic explanatory style because they consider their incompetence to be transitory. Moreover, as far as the success expectancies are concerned, the more optimistic the explanatory style is, the higher the expectancies are (Figure 2a).

Second, the results confirmed the role played by the explanatory style as only a distal variable (e.g., Peterson \& Park, 1998; Peterson \& Vaidya, 2001; Peterson \& Steen, 2002; Martin-Krumm et al., 2003). According to some previous studies carried out in other academic subject (e.g., Peterson \& Barrett, 1987), the results showed that the explanatory style was a correlate of the students' grades in PE during all the school-year $(r=.26, p<.05)$. Nevertheless, when some other variables are controlled (e.g., success expectancies and subjective task value), explanatory style did not affect the students' GPEC (Figure 3). In other 
words, the effects of explanatory style on students' GPEC are mediated by more proximal variables, as suggested by Eccles and her colleagues (e.g., Eccles et al., 1983, 1998): success expectancies and subjective task value.

Although the present results provided support for the suggested model, some limitations should be acknowledged and kept in mind when interpreting the findings. First of all, as with all correlational data, these results must be interpreted cautiously insofar as predictor variables (e.g., explanatory style) were not manipulated. Although a reciprocal causal link is not plausible given the longitudinal data (e.g., final students' GPEC cannot have caused perceived ability or explanatory style at the beginning of the school-year), it is difficult to make sure that all relevant variables have been taken into account. Thus, the ascertained links between the variables can be due to other variables which have not been measured (see Judd \& McClelland, 1989). Among the omitted potential variables, it would have been interesting to have at our disposal an objective indicator of the students' real ability in PE, and other personality variables like self-esteem, anxiety, or negative affectivity. Thus, future researches should probably control such as variables.

Along these lines, the marks given by the teacher for the students' performances may not be the correct reflection of the students' achievement in PE. As emphasized by Jussim (1991), marks can be biased by the teacher's beliefs or his a priori opinion. In other words, the performance measure used in this study may have underestimated the model variables effects. Future studies should have recourse to another performance indicator to reduce this possible bias.

According to self-concept models (e.g., Harter, 1990; Marsh, 1990; Skaalvik, 1997), our study confirmed the links between the self-concept of one's ability and performances. Nevertheless and according to the Eccles et al.'s expectancies-value model (e.g., 1983 ; 1998 ; Eccles \& Wigfield, 2002), our results tend to show that other variables like success 
The moderating effects of Explanatory Style

expectancies and subjective task value are also linked to achievement. More important, they show that the styles used by the students to explain their successes or their failures played a significant role. An optimistic explanatory style may buffer a low perceived ability whereas a pessimistic one tend to increase the armful effects of a low perceived ability.

Thus, from an applied perspective, it seems important to enhance at the same time the self-concept of pupils' ability, and their self-confidence to increase their own competences at school, in particular by reinforcing an optimistic way of looking into the causes of events at school. 
References

Abramson, L. Y., Seligman, M. E. P., \& Teasdale, J. (1978). Learned Helplessness in Humans: Critique and Reformulation. Journal of Abnormal Psychology, 87, 49-74.

Aiken, L., \& West, S. (1991). Multiple Regression: Testing and Interpreting Interactions. Newbury Park, CA : Sage.

Anderson, J. C., \& Gerbin, D. W. (1988). Structural equation modeling in practice: a review and recommended two-step approach. Psychological Bulletin, 103, 411-423.

Bridges, K. R. (2001). Using attributional style to predict academic performance: how does it compare to traditional methods ?. Personality and Individual Differences, 31, 723-730.

Corr, P. J., \& Gray, J. A. (1995). Relationship between attributional style and lie scores in an occupational sample motivated to fake good. Personality and Individual Differences, 18 , $433-445$.

Cutrona, C. E., Russel, D., \& Jones, R. (1985). Cross-situational consistency in causal explanations: Does attributional style exist? Journal of Personality and Social Psychology, 47, 1043-1058.

Dua, J. K. (1995). Comparative and prospective psychological and physical health as a function of negative affect and attributional style. Journal of Clinical Psychology, 51, 507-518.

Eccles, J. S., Adler, T. F., Futterman, R., Goff, S. B., Kaczala, C. M., Meece, J. L., \& Midgley, C. (1983). Expectancies, values, and academic behaviors. In T. J. Spence (Ed.), Achievement and achievement motivation (pp. 75-146). San Francisco, CA: W. H. Freeman.

Eccles, J. S., \& Wigfield, A. (2002). Motivational Beliefs, Values, and Goals. Anmual Review of Psychology, 53, 109-132. 
Eccles, J. S., Wigfield, A., \& Schiefele, U. (1998). Motivation to succeed. In W. Damon (Series Ed.) and N. Eisenberg (Vol. Ed.), Handbook of child psychology ( $5^{\text {th }}$ ed., Vol. III, pp. 1017-1095). New York: Wiley.

Fazio, N. M., \& Palm, L. J. (1998). Attributional style, depression, and grade point averages of college students. Psychological Reports, 83, 159-162.

Hanrahan, S., Grove, J. R., \& Hattie, J. A. (1989). Development of a questionnaire measure of sport-related attributional style. International Journal of Sport Psychology, 20, 114-134.

Harter, S. (1990). Causes, correlates and the functional role of global self-worth : A life span perspective. In J. Kolligian \& R. Stenberg (Eds.), Perceptions of competence and incompetence across the life span (pp. 67-98). New Haven, CT : Yale University Press.

Henry, J. W., Martinko, M. J., \& Pierce, M. A. (1993). Attributional style as a predictor of success in a first computer science course. Computers in Human Behavior, 9, 341-352.

Houston, D. M. (1994). Gloomy but smarter: the academic consequences of attributional style. British Journal of Social Psychology, 33, 433-441.

Jackson, B., Sellers, R. M., \& Peterson, C. (2002). Pessimistic explanatory style moderates the effect of stress on physical illness. Personality and Individual Differences, 32, 567573.

Jöreskog, K., \& Sörbom, D (1999). Lisrel 8.30: User's Reference Guide. SSI Inc.: Chicago. Judd, C.M., \& McClelland, G.H. (1989). Data Analysis: A model-comparison approach. Orlando, FL: Harcourt Brace Jovanovitch.

Jussim, L. (1991). Social perception and social reality: A reflection-construction model. Psychological Review, 98, 54-73.

Kim, J. S., Kaye, J., \& Wright; L. K. (2001). Moderating and mediating effects in causal models. Issues in Mental Health Nursing, 22, 63-75. 
McIver, D. J., Stipek, D. J., \& Daniels, D. H. (1991). Explaining within-semester changes in student effort in junior high school and senior high school courses. Journal of Educationnal Psychology, 83, 201-211.

Marsh, H. W. (1990). The causal ordering of academic self-concept and academic achievement: A multiwave, longitudinal path analysis. Journal of Educational Psychology, 82, 646-656.

Martin-Krumm, C., Sarrazin, P., Fontayne, P., \& Famose, J. P. (2001). Validation of the Physical Education and Sport Explanatory Style Questionnaire. Proceeding of the ninth International Congress of the French Association of sport and exercise researchers. Valence, France, November 1-3.

Martin-Krumm, C., Sarrazin, P., Peterson, C., \& Famose, J.P. (2003). Explanatory style and resilience after sports failure. Personality and Individual Differences, 35, 1685-1695.

Nicholls, J. G., Patashnick, M., \& Nolen, S. B. (1985). Adolescents' theories of education. Journal of Educational Psychology, 77, 683-692.

Pajares, J., \& Schunk, D. H. (2001). Self-efficacy, self-concept, and academic achievement. In J. Aronson \& D. Cordova (Eds.). Psychology of education: Personal and interpersonal forces. New. New York: Academic Press.

Peterson, C. (1991) Meaning and measurement of explanatory style. Psychological Inquiry, 2, $1-10$.

Peterson, C. (2000). The future of optimism. American Psychologist, 55, 44-54.

Peterson, C., \& Barrett, L. (1987). Explanatory style and academic performance among university freshmen. Journal of Personality and Social Psychology, 53, 603-607.

Peterson, C., Bishop, M. P., Fletcher, C. W., Kaplan, M. R., Yesko, E. S., Moon, C. H., Smith, J. S., Michaels, C. E., \& Michaels, A. J. (2001). Explanatory style as a risk factor for traumatic mishaps, Cognitive Therapy and Research, 25, 633-649. 
Peterson. C., \& Park, C. (1998). Learned helplessness and explanatory style. In D. F. Barone, V. B. Van Hasselt, M. Hersen (Eds) Advanced personality (pp. 287-310), New York: Plenum.

Peterson, C., \& Steen, T. A. (2002). Optimistic explanatory style. In C. R. Snyder \& S. J. Lopez (Eds), Handbook of positive psychology (pp. 244-256), Oxford University Press.

Peterson, C., \& Vaidya, R. S. (2001). Explanatory style, expectations, and depressive symptoms. Personality and Individual Differences, 31, 1217-1223.

Petripin, G. L., \& Johnson, M. E. (1991). Effects of gender, attributional style, and items difficulty on academic performance. Journal of Psychology, 125, 45-50.

Reivich, K. (1995). The measurement of explanatory style. In G. M. Buchanan \& M. E. P. Seligman (Eds), Explanatory style (pp. 21-47). Hillsdale, NJ: Erlbaum.

Sarrazin, P., Roberts, G., Cury, F., Biddle, S., \& Famose, J.-P. (2002). Exerted effort and performance in climbing among boys: The influence of achievement goals, perceived ability, and task difficulty. Research Quarterly for Exercise and Sport, 73(4), 425-436.

Seligman, M. E. P. (1991). Learned Optimism. New York : Knopf.

Skaalvik, E. (1997). Issues in research on self-concept. In M. Maehr and P. Pintrich (Eds), Advances in Motivation and Achievement, Volume 10 (pp. 51-97). London: JAI Press Inc.

Tiggemann, M., \& Crowley, J. R. (1993). Attributions for academic failure and subsequent performance. Australian Journal of Psychology, 45, 35-39.

Volpe, N., \& Levin, R. (1998). Attributional style, dreaming, and depression. Personality and Individual Differences, 25, 1051-1061.

Wigfield, A., \& Eccles, J. S. (2000). Expectancy-value Theory of Achievement Motivation. Contemporary Educational Psychology, 25, 68-81. 
The moderating effects of Explanatory Style

\section{Footnotes}

${ }^{1}$ As explanatory style research has progressed and theory has been modified, the internality dimension has become of less interest (Peterson, 1991, 2000; Peterson \& Steen, 2002) and less likely to be examined in empirical studies (e.g., Peterson \& Vaidya, 2001; Peterson, Bishop, Fletcher, Kaplan, Yesko, Moon, Smith, Michaels, \& Michaels, 2001).

${ }^{2}$ In order to test the possible moderation of explanatory style in the relationships between success expectancies and/or subjective task value, and students' GPEC, this last variable was regressed onto explanatory style, success expectancies, subjective task value, as well as onto three interaction terms: success expectancies $\times$ explanatory style, subjective task value $\times$ explanatory style, and success expectancies $\times$ subjective task value $\times$ explanatory style. None of these interaction terms were significant.

${ }^{3}$ We carried out a confirmatory factor analysis (CFA) in order to test the construct and discriminant validities of the three variables the more correlated (perceived ability, success expectancies, and subjective task value). The CFA model was based on the 9 observed measures and the 3 presumed underlying constructs. The results provided an adequate fit to the data (e.g., NFI $=.92 ; \mathrm{CFI}=.94 ; \mathrm{RMSR}=.047)$. All $\lambda$ were significant $(t>2.00)$ and considerable $(\geq .68)$. To test the discriminant validity of the constructs, we examined whether each pair of latent factors could be treated as a single construct by setting each correlation to 1.0 and comparing the constrained model to the original model in which the correlation was free to vary (see Anderson \& Gerbin, 1988). These tests were performed separately for each pair of latent constructs. Chi-square difference tests indicated that each correlation was significantly different from 1.0 (all $p s<.001)$ thereby supporting the discriminant validity of these three constructs. 
Table 1

Descriptive information for measures of perceived ability, explanatory style, subjective task value, success expectations, and performances

\begin{tabular}{|c|c|c|c|c|c|}
\hline Variables & 1 & 2 & 3 & 4 & 5 \\
\hline 1. Perceived ability & - & $.38 * *$ & $.48 * *$ & $.78^{* *}$ & $62^{* *}$ \\
\hline 2. Explanatory Style & & - & $.31 * *$ & $.34 * *$ & $26^{*}$ \\
\hline 3. Subj. task value & & & - & $.51^{* *}$ & $.45^{* *}$ \\
\hline 4. Success expect. & & & & - & $63 * *$ \\
\hline 5. Students' GPEC & & & & & - \\
\hline Mean & 4.59 & 0.56 & 5.79 & 4.75 & 14.29 \\
\hline S.D. & 1.31 & 1.14 & 1.46 & 1.10 & 2.28 \\
\hline
\end{tabular}

Note. ${ }^{*} p<.05 ;{ }^{* *} p<.01$ 
Table 2

Co-Variance Matrix between the different variables

\begin{tabular}{lcccccr} 
Variables & 1 & 2 & 3 & 4 & 5 & \multicolumn{1}{c}{6} \\
\hline 1. Subj. task value & 2.14 & .83 & 1.49 & .47 & .72 & -.60 \\
2. Success expect. & - & 1.20 & 1.58 & .38 & .87 & .02 \\
3. GPEC & & - & 5.19 & .61 & 1.45 & -.15 \\
4. Z_Exp. Style & & & - & 1.06 & .40 & .10 \\
5. Z_Per. ability & & & & - & 1.04 & -.17 \\
6. Z PA $\times$ ES & & & & & - & 1.79 \\
\hline
\end{tabular}

Note. $\mathrm{Z}=$ Standardized value of Explanatory Style (ES) and Perceived Ability (PA). GPEC = Grades Average in PE. 
The moderating effects of Explanatory Style

Figure 1. Theoretical model.

Figure Captions

Figure 2. a. Moderating effect of Explanatory Style on the relationships between perceived ability and success expectancies.

b. Moderating effect of Explanatory Style on the relationships between perceived ability and subjective task value.

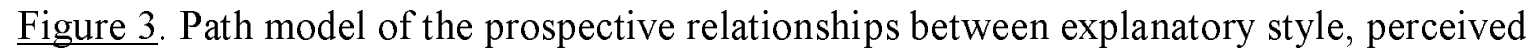
ability, success expectations, subjective value and students' grades in PE. 


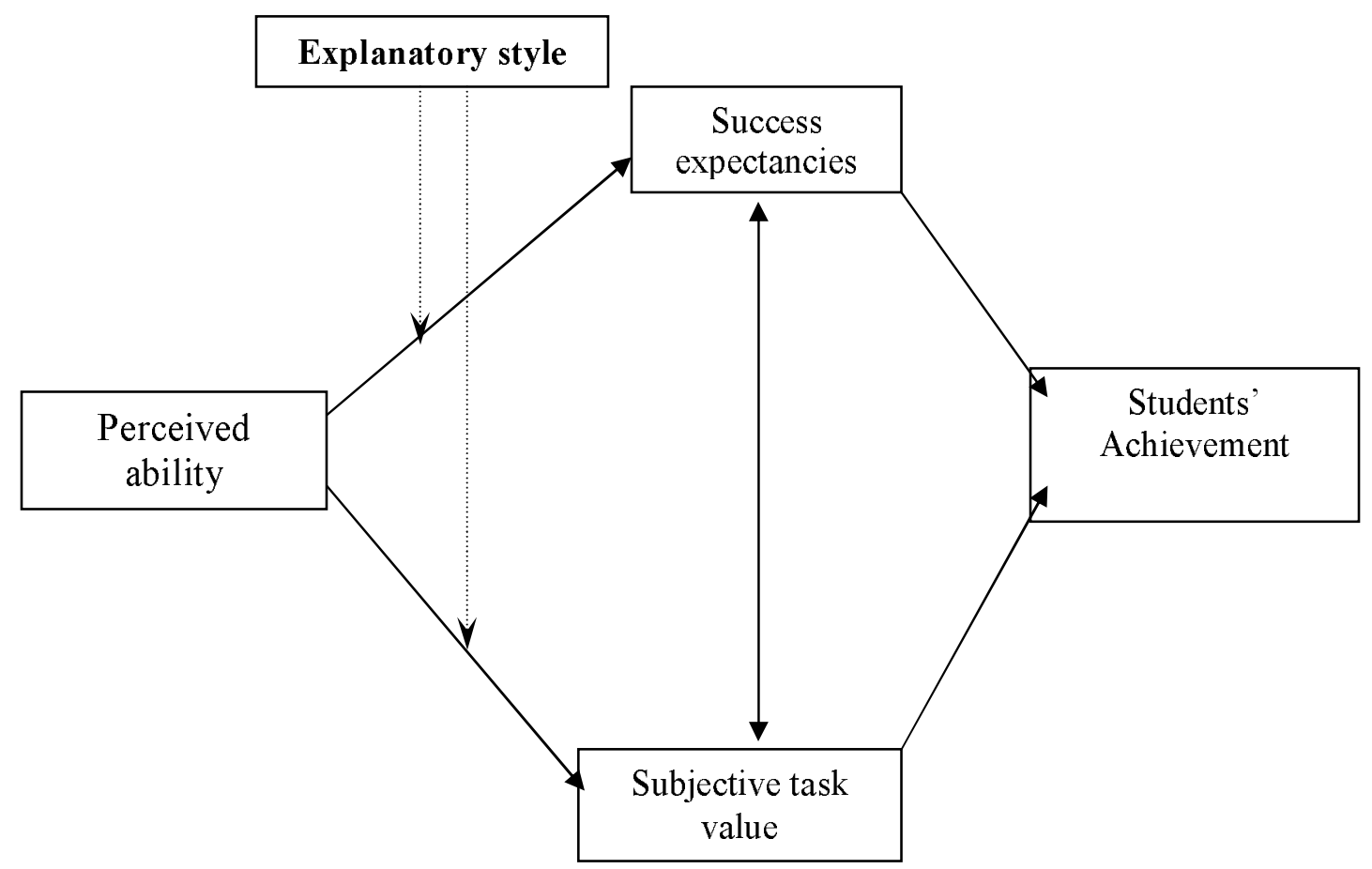




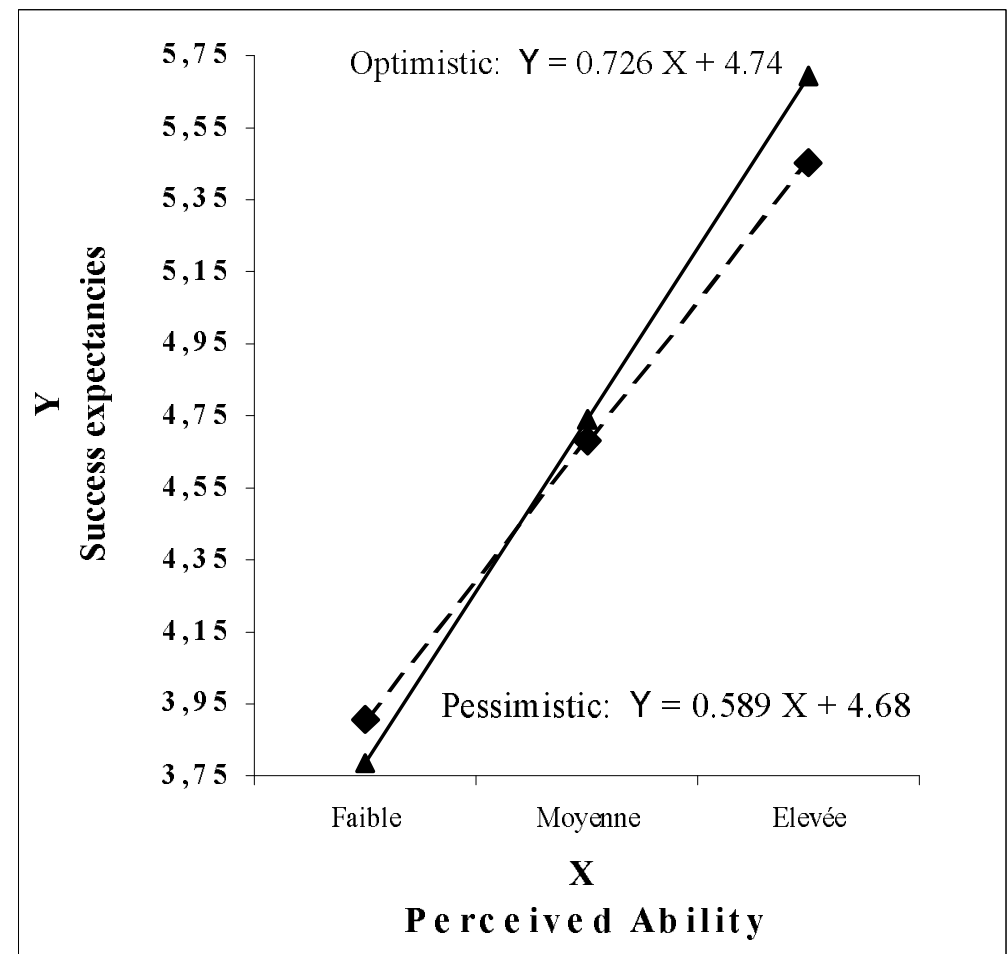

a.

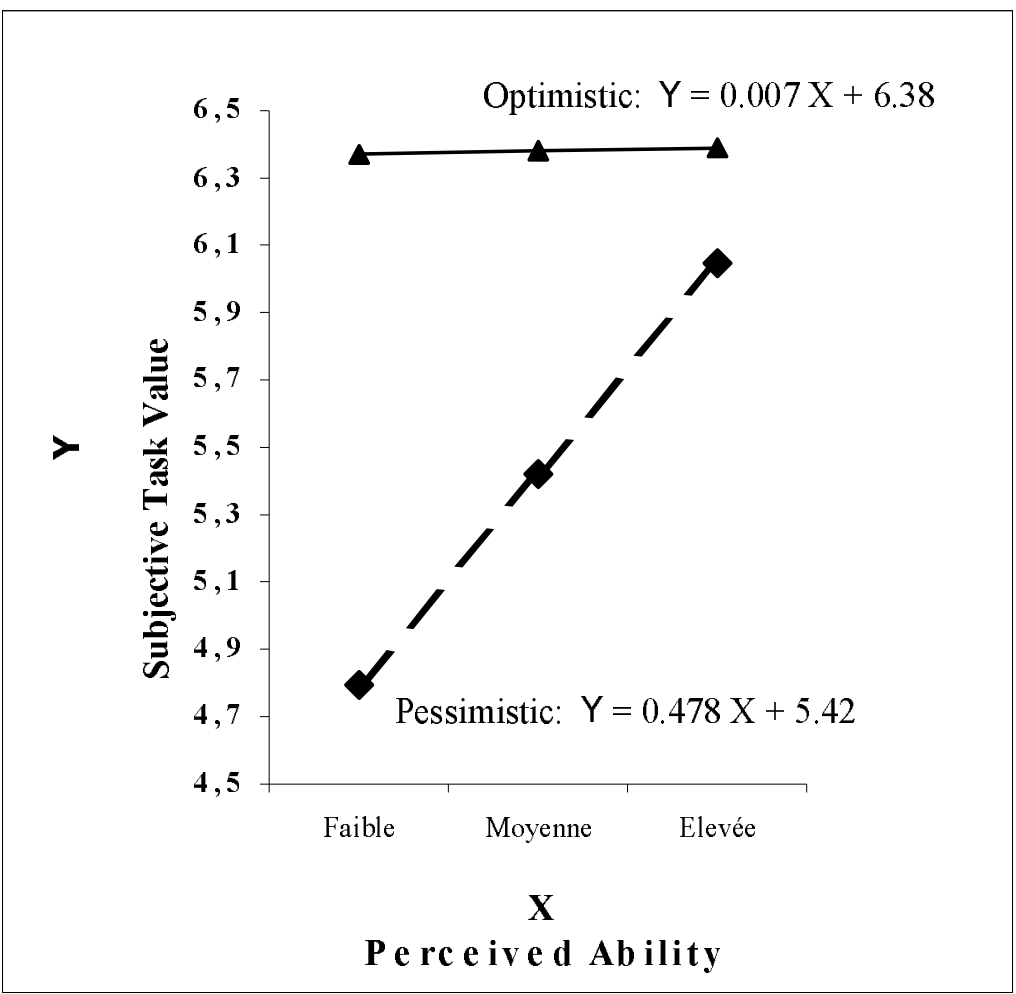

b. 
The moderating effects of Explanatory Style

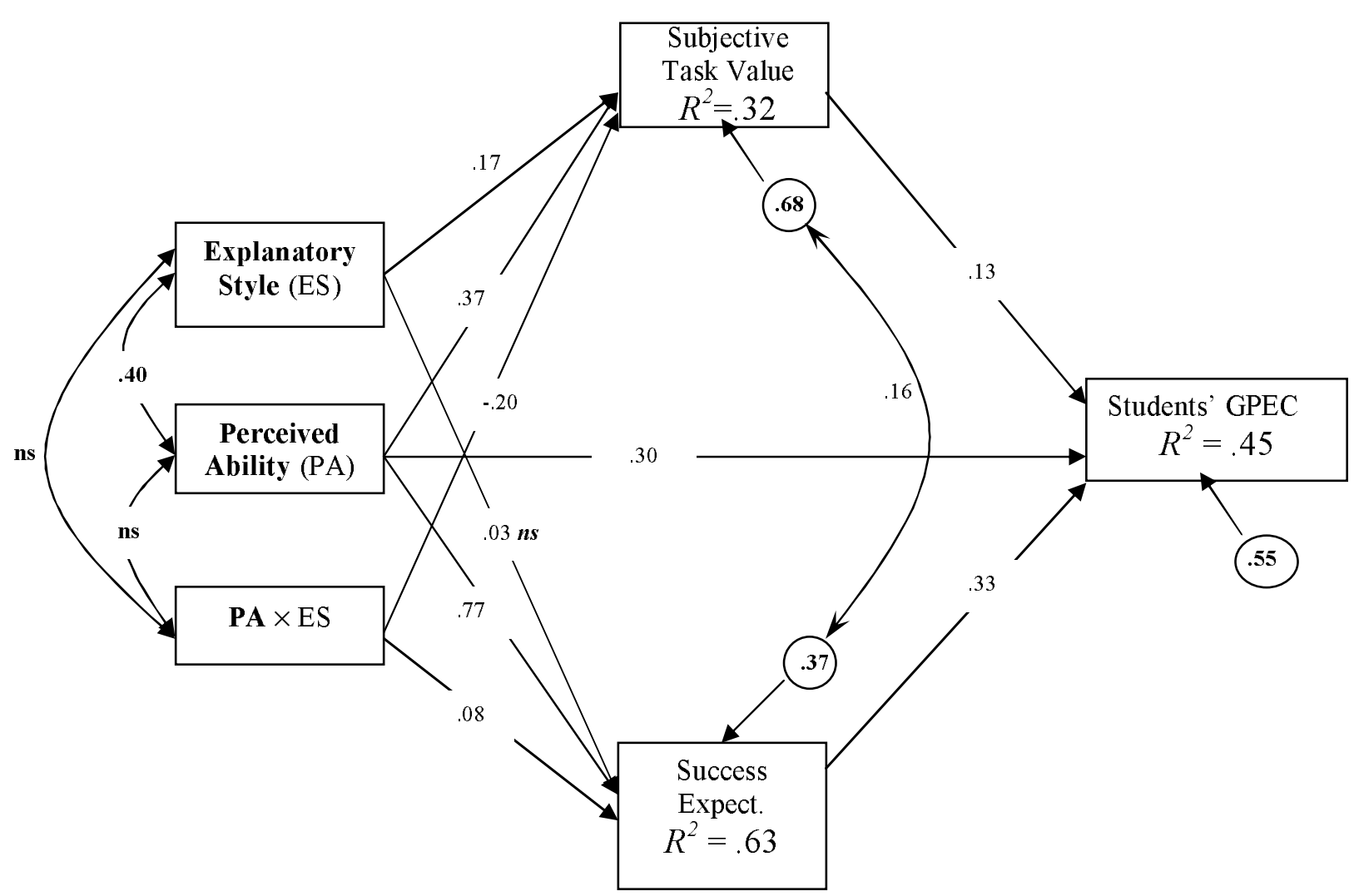

